\title{
II. Abdülhamid Döneminde Osmanlı Devleti ile İngiltere Arasında Afgan Muhacirleri Meselesi ${ }^{1}$
}

\begin{abstract}
Musa KILIÇ ${ }^{2}$
$\ddot{\mathbf{O z}}$

II. Abdülhamid döneminde muhacir meselesi Osmanlı Devleti'ni meşgul eden önemli sorunlardan biriydi. Osmanlı topraklarına göç edenlerden bir kısmını da Afgan muhacirleri oluşturmaktaydı. II. Abdülhamid döneminde Afgan göçlerinin başlıca sebepleri arasında 1878'de başlayan İkinci Afgan-İngiliz Savaş1, Abdurrahman Han'ın iktidara gelmesinden sonra iç siyasette izlediği sert politika ile İngiltere ve Rusya'nın bölge üzerindeki rekabeti sonrasında Afganistan'da huzursuzluğun arttırmas1 gibi etkenleri sıralayabiliriz. Osmanlı Devleti başta Irak, Suriye ve Hicaz olmak üzere çeşitli bölgelere yerleştirilen Afgan muhacirlere elinden gelen yardımı göstermeğe çalışmıştı. Fakat İngiltere, Afganistan'ın bir kısım topraklarının doğrudan kendi kontrolleri altında olduğunu ve Afgan Emirinin diş politikada kendilerine bağlı bulunduğunu ileri sürerek Osmanlı topraklarına göç etmiş olan Afganların İngiltere tâbiiyetinde ve himayesinde olduklarını iddia etmekteydi. Osmanlı Devleti ise Afgan muhacirleri kendi himayesinde ve Hilafet kurumunun koruması altında kabul etmiş ve Osmanlı tâbiiyetine geçmek isteyen Afgan muhacirlere kolaylık sağlamıştı.
\end{abstract}

Anahtar Kelimeler: Afganistan, Osmanlı Devleti, İngiltere, Muhacir, Göç

\section{The Issue of Afghan Refugees Between The Ottoman State And The Britain In The Period Of Abdulhamid II}

\begin{abstract}
During the reign of Abdülhamid II, the issue of immigrants was one of the important issues that occupied the agenda of the Ottoman Empire. Afghan immigrants were also a part of those who migrated to Ottoman lands. Among the main reasons for Afghan immigration during the reign of Abdulhamid II we can list the factors such as the Second Afghan-British War that started in 1878, the harsh domestic politics followed by Abdurrahman Khan after he came to power, and the increased unrest in Afghanistan after the rivalry between England and Russia over the region. The Ottoman Empire tried to help the Afghan immigrants who were settled in various regions, especially Iraq, Syria, and the Hejaz. However, Britain claimed that some lands of Afghanistan were under their direct control and that the Afghan Emir was dependent on them in foreign policy, and that the Afghans who had migrated to the Ottoman lands were under the British nationality and patronage. The Ottoman Empire, on the other hand, accepted Afghan immigrants under its auspices and under the
\end{abstract}

\footnotetext{
${ }^{1}$ Bu makale, 27 - 28 Kasım 2017 tarihleri arasında Anadolu Üniversitesi tarafından düzenlenen Uluslararası Türkiye - Afganistan İlişkileri Sempozyumu'nda “Osmanlı Devleti ile İngiltere Arasında Afgan Muhacirlerin Himayesi ve Tâbiiyeti Meselesi” başlığıyla sunulan yayınlanmamış tebliğin gözden geçirilmiş ve düzeltilmiş hâlidir.

2 Doç. Dr. Eskişehir Osmangazi Üniversitesi, Fen-Edebiyat Fakültesi, Tarih Bölümü. musakilic@ogu.edu.tr
} 
protection of the caliphate, and provided convenience to Afghan immigrants who wanted to become Ottoman nationals.

Key Words: Afghanistan, Ottoman State, Britain, İmmigrant, Migration

\section{Giriş}

II. Abdülhamid döneminde Osmanlı topraklarına ciddi bir muhacir göçü söz konusudur. Bu göçmenlerin büyük bölümünü gerek 93 Harbi sırasında ve gerekse savaş sonrasında Sırbistan, Romanya ve Bulgaristan gibi Balkan ülkelerinden göç etmek zorunda kalanlar oluşturmaktaydı. Bu göç dalgası o kadar büyüktü ki Balkan muhacirlerin ihtiyaçlarını karşılamak için çeşitli komisyonlar kurulmuştu. ${ }^{3}$ Fakat II. Abdülhamid dönemindeki göçler sadece Balkanlar ile sınırlı değildi. Bunların dışında, ülkelerinin sömürgeci güçler tarafından işgali nedeniyle Cezayir, Tunus, Kafkasya ve Orta Asya gibi bölgelerden İslam hilafetinin merkezi olması hasebiyle Osmanlı topraklarına sığınan pek çok Müslüman muhacir bulunmaktaydı. Fakat işgalci Avrupalı devletler, muhacirlerin kendi himaye ve tâbiiyetlerinde olduğu iddiasını dile getirmekteydiler. Osmanlı Devleti ise bu iddiaları hem kendi kanunlarına aykırı bulduğundan hem de İslam halifesinin Müslümanları himayesi altına almasını doğal bir hak olarak kabul ettiği için Batılı ülkeler tarafından ileri sürülen tezleri reddetmekteydi.

Sömürgeci devletlerin muhacirlere yönelik himaye ve tâbiiyet iddiaları işgal ettikleri topraklarda meşruiyet sağlamaları açısından önemliydi. Batılı devletler bu iddialarını, özellikle Osmanlı topraklarında muhacirlerin iskân edildiği bölgelerde, nüfuz ve etkilerini arttırmak için de kullanıyorlardı. Ayrıca İslam dünyasının halifesi olan Osmanlı Sultanının muhacirleri himayesi etmesini kendileri için bir tehdit olarak da görüyorlardı. Osmanlı Devleti açısından ise Batılı devletlerin iddiaları, iç işlerine müdahale anlamına gelmekteydi. Dolayısıyla Osmanlılar, himaye ve tâbiiyet tartışmalarında Batılı devletlere karşı elinden gelen direnci göstermeğe çabalayacaktı. Söz konusu hukuki tartışmalarda Osmanlıların en önemli argümanı, muhacirlerin hilafet merkezi olan Osmanlı Devleti'nin misafirleri olduğu ve doğal olarak halifenin himayesinde bulunduğuydu.

Tâbiiyet ve himaye tartışmalarının ilk örneğini, sömürgeci bir devlet tarafından kalıcı şekilde işgal edilen ilk Osmanlı toprağı olan Cezayir'den gelen muhacirler meselesinde görmek mümkündür. Cezayir'deki direniş hareketinin kırıldığg 1847 yılından sonra pek çok Cezayirli Osmanlı topraklarına göç etmişti. Fransa'nın Osmanlı topraklarına göç eden Cezayirlileri kendi tebaasından olduğunu iddia etmesi uzun yıllar boyunca Osmanlı Devleti'nin gündemini meşgul etmişti. ${ }^{4}$

Batılı devletlerin sömürgelerinden gelen muhacirlerin tâbiiyet ve himaye tartışmaları Cezayir meselesiyle münhasır kalmadı. Özellikle II. Abdülhamid döneminde Kafkasya ve Orta Asya'dan yüz binlerce Müslümanın Osmanlı topraklarına göç

\footnotetext{
${ }^{3}$ Nedim İpek, Rumeli'den Anadolu'ya Türk Göçleri (1877-1890), Ankara 1994, s. 74-77.

${ }^{4}$ Fransa işgalinin ardından Osmanlı topraklarınad göç eden Cezayirli muhacirler için bkz. Ş. Tufan Buzpınar, "Suriye'ye Yerleşen Muhacirlerin Tâbiiyeti Meselesi (1847-1900)" İslâm Araştırmaları Dergisi, S. 1, 1997, s. 91-106.
} 
etmesinden sonra bu göçmenlerin tâbiiyeti konusundaki tartışmalar gündemdeki yerini sürekli korudu. Nitekim İngiltere ile Osmanlı Devleti arasında Afgan muhacirlerin himaye ve tâbiiyeti sorunu da bu dönemde s1k sık gündeme gelecekti.

\section{İngiltere'nin Afgan Muhacirleri Üzerinde Himaye İddiaları}

Afganistan 1830'lardan itibaren iki sömürgeci gücün tehdidiyle karşılaşmıştı. Bunlardan biri Orta Asya'da yayılan Rusya'ydı. Fakat Hindistan'a hâkim durumdaki İngiltere daha büyük bir tehdit konumundaydı. Nitekim 1839-1842 yılları arasında gerçekleşen ilk Afgan-İngiliz Savaşı ülkede büyük bir tahribata neden olmuştu. Buna rağmen Afgan toprakları, İngiltere tarafından işgal edilememişti. ${ }^{5}$ İngiltere 1878 'de bir kez daha Afganistan'1 işgal girişiminde bulunacaktı. Bu savaş Afganistan'dan Osmanlı topraklarına ilk büyük çapta göç hareketini tetikleyecekti. 1880 yılında tahta çıkan Abdurrahman Han'ın iktidarını sağlamlaştırmak ve merkezi otoriteyi tesis etmek için başlattığı mücadele ${ }^{6}$ bu göç hareketini hızlandırdı. Nitekim aralarında hanedan üyeleri, aşiret reisleri ve din adamlarının da olduğu pek çok Afganlı muhalif Osmanlı topraklarına göç etmek zorunda kaldı. Afgan muhacirler Osmanlı hükümeti tarafından başta Bağdat, Basra, Suriye ve Tarsus olmak üzere çeşitli bölgelere yerleştirildiler.

Afgan muhacirlerinin göçlerinin gerçekleştiği ilk yıllarda İngiltere ve Osmanlı Devleti arasında bu insanları tâbiiyetleri ve himayeleri konusunda ciddi bir tartışmanın olmaması dikkat çekicidir. Fakat 1880'li yılların ortalarından itibaren İngiltere'nin Afgan muhacirleri konusunda himayeci bir politika izlemeye başladığı görülmektedir. İngiltere'nin bu tutum değişikliğinin Osmanlı Devleti'yle arasındaki siyasal ilişkilerde yaşanan kırılmadan kaynaklandığ 1 söyleyebiliriz. Aslında II. Abdülhamid'in saltanatının ilk yıllarında Osmanlı Devleti ile İngiltere arasında Afganistan meselesinde ortak çıkarlar söz konusuydu. 93 Harbi sırasında II. Abdülhamid'in Afganistan'a bir elçilik heyeti gönderme fikri İstanbul'daki İngiliz elçisi Henry Layard tarafından Afgan topraklarındaki Rus tehdidine karşı yararlı olacağ 1 düşüncesiyle olumlu karşılanmış ve bu düşüncesini Londra hükümetine kabul ettirmişti. Nitekim elçi olarak görevlendirilen Ahmed Hulusi, Kabil'de huzuruna çıktığı Şir Ali Han'a Osmanlı Devleti'nin dost ve müttefiki olan İngiltere Devleti ile ilişkilerini geliştirme tavsiyesinde bulunmuştu. ${ }^{7}$ Fakat 93 Harbi sonrasında İngiltere ile Osmanlı Devleti arasındaki ilişkiler yavaş yavaş bozulmaya başlamıştı. Osmanlı Devleti'nin izlediği Afgan politikası, Ingilizler tarafından II. Abdülhamid'in Panislamist siyasetinin bir parçası olarak görülmeye başlandı. Nitekim 1878'de patlak veren II. Afgan-İngiliz savaşından sonra Afganistan'da hegemonyasını kuran İngiltere, II. Abdülhamid'in arzusuna rağmen Osmanlı Devleti'nin bölgede etkili

\footnotetext{
${ }^{5}$ Orhan Yazıcı, "Birinci İngiliz-Afgan Savaşı ve Sonuçları", Afganistan Üzerine Araştırmalar, Yay. Haz. Ali Ahmetbeyoğlu, TATAV Yayınları, İstanbul 2002, s. 80-81.

${ }^{6}$ Orhan Yazıcı," Emir Abdurrahman Han'ın Afganistan'da Merkezî Otoriteyi Tesis Etme Çabaları", Orta Doğu Araştırmaları Dergisi, C. VII, S. 1, Ocak 2009, s. 95-118.

${ }^{7}$ Azmi Özcan, "II. Abdülhamid Döneminde Afganistan ile İlişkiler ve İngiltere”, Afganistan Üzerine Araştırmalar, Yay. Haz. Ali Ahmetbeyoğlu, TATAV Yayınları, İstanbul 2002, s. 86-92.
} 
olmasına izin vermeyecekti. Hatta kendi aleyhine Afgan topraklarında ortaya çıkan bazı olaylardan Osmanlı'yı sorumlu tutacaktı.

Böyle bir süreçte İngiliz Hükümeti’nin Osmanlı topraklarında yaşayan bazı Afgan muhacirlerin İngiltere'nin himayesinde ve tabiiyetinde oldukları iddialarını gündeme alması dikkat çekicidir. Nitekim ilk olarak 1886 yılında, 30 seneden beri Bağdat'ta ikamet eden Hacı Habib adlı bir Afgan'ın İngiltere tebaasından olduğunu iddia etmesi üzerine tâbiiyet konusu gündeme gelmiş ve bu meselenin müzakeresi Şûrâ-yı Devlet'in Tanzimat Dairesine bırakılmıştı. Tanzimat Dairesi ise konu hakkında bir rapor hazırlanması işini Babıali Hukuk Müşavirliğine havale etmişti. Babıali Hukuk Müşavirliği tarafından hazırlanan raporda Orta Asya kökenli olan ve bir süreden beri Osmanlı topraklarında ikamet eden bazı kimselerin, İngiltere veya Rusya tâbiiyetinde bulundukları iddiasını dile getirdikleri ve meselenin hassasiyetinden dolayı bu soruna bir çözüm bulunması gerektiğine işaret edilmekteydi. Raporun devamında, bir ülkenin başka bir ülke tarafından işgali sonrasında orada yaşayanların tâbiiyeti kabul etmeyerek göç etmeğe haklarının olması hususunun uluslararası hukuk tarafından tanındığı belirtiliyordu. Bu nedenle aslen Orta Asya'nın hükümet ve aşiretlerine mensup muhacirlerin yabancı bir ülke tâbiiyetinde sayılamayacağ ifade ediliyordu. ${ }^{9}$ Raporda ayrıca 1869 yılında çıkarılan Osmanlı Tâbiiyet Kanunu'nun dokuzuncu maddesindeki "Memâlik-i Mahrusa-i Padişahîde ikamet eden her bir şahıs Tebaa-yi Devlet-i Âliyye'den madud olup hakkında Devlet-i Âliyye tâbiiyeti muamelesi icra olunur. Ĕger kendisi tâbiiyet-i ecnebiyeden ise tâbiiyetini ispat etmesi lâzım gelir" şeklinde hükmüne de referans verilmekteydi. ${ }^{10}$ Osmanlı Devleti'ne göç eden muhacirlerin Osmanlı kanunlarına uymak, vergi mükellefiyeti konusunda Osmanlı tebaası ile aynı yükümlülükleri yerine getirmek ve Osmanlı mahkemelerinde yargılanmak gibi mükellefiyetleri de bulunmaktaydı. Yine söz konusu değerlendirmelerde yer alan ifadelere göre, muhacirlerin yabancı bir ülke tâbiiyetinde sayılabilmesi için pasaport gibi bir belgeyi ibraz etmeleri gerekmekteydi. Raporun devamında Orta Asya ve Hindistan'da birçok hükümet ve aşiretin Rusya veya İngiltere himayesinde bulunmalarına rağmen istiklal ve muhtariyetlerini az çok muhafaza ettikleri ve bundan dolayı yabancı devletlerin muhacirlere yönelik himaye iddiasına hakları olmadığı vurgulanmaktadır. Üstelik bu hükümet ve aşiretler dışişlerini tamamen himaye altında bulundukları devletlere bıraksalar bile bu bölgelerden göç eden muhacirlerin Batılı devletlerin aslî vatandaşı olarak görülemeyeceği ve Avrupalı devletlerin vatandaşlarının haiz olduğu imtiyazlardan kesinlikle yararlanamayacağı belirtilmekteydi. ${ }^{11}$

Babıali Hukuk Müşavirlerinin hazırladığı raporun sonunda farklı bir noktaya daha dikkat çekilmektedir. Bilindiği gibi kapitülasyonlardan, zaman içerisinde Osmanlı tebaası olan bazı gayrimüslimler de yararlanarak yabancı devletlerin koruması altında olduklarını iddia etmişler ve başta vergi mükellefiyeti olmak üzere bazı sorumlulukları yerine getirmemeye başlamışlardı. Osmanlı Devleti, özellikle

\footnotetext{
${ }^{8}$ Agm., s. 97-102.

${ }^{9}$ BOA., ŞD, 2505/15/7, 1 Mart 1886.

${ }^{10}$ Cihan Osmanağaoğlu, Tanzimat Dönemi Itibariyle Osmanlı Tâbiiyetinin (Vatandaşlığının) Gelişimi, Legal Yayıncılık, İstanbul 2004, s. 199.

${ }^{11}$ BOA., ŞD., 2505/15/7, 1 Mart 1886.
} 
XIX. yüzyılın ikinci yarısında aldığı bazı tedbirlerle, bu suiistimallerin önüne geçmeye çalışmıştı. ${ }^{12}$ Raporda tâbiiyet kanunun neşredilmesinden sonra Osmanlı tebaası olmasına rağmen yabancı devletlerin koruma ve himayesinde olan sinıfların büyük oranda ortadan kalktığını ancak yabancı devletlerin muhacirler üzerindeki himaye haklarının onaylanması durumunda bu sorunun yeniden gündeme gelebileceği çekincesi dile getirilmekteydi. ${ }^{13}$

Şûrâ-yı Devlet Tanzimat Dairesi, Orta Asya memleketlerinden gelen muhacirlerin Osmanlı kanunlarına tabi olmaları ve Batılı devlet vatandaşlarına sağlanan imtiyazlardan yararlanamamaları konusunda Babıali Hukuk Müşavirleri ile aynı görüşteydi. Ayrıca daha önce Afgan ve diğer Orta Asya muhacirlerinin başka ülkelerin tâbiiyet ve himayesinde bulunduklarına dair herhangi bir iddialarının olmadığına dikkat çekilmekteydi. Eğer bu durum bir hukuki kaide şekline getirilerek engellenmek istenirse, Orta Asya'da sömürgesi olan devletlerin tepkisini çekebileceği ve devamının geleceği endişesi dile getirilmekteydi. O sebeple muhacirlerin yabancı ülke tâbiiyeti iddialarının ayrı ayrı olarak uluslararası hukuk çerçevesinde ele alınmasına karar verilmişti. ${ }^{14}$

Şûrâ-yı Devlet Tanzimat Dairesi'nin bu kararından bir süre sonra Dâhiliye Nezareti tarafından taşradaki vilayet memurlarına, Afgan muhacirlerin Devlet-i Âliyye'nin himayesinde olduğu ve ona göre işlem yapılmasına dair bir talimat gönderilecekti. $\mathrm{Bu}$ talimatın taşradaki İngiliz konsoloslarına tebliği üzerine İstanbul'daki İngiltere Büyükelçiliği 8 Nisan 1890 tarihli bir yazı ile itirazda bulundu. İngiliz büyükelçiliğine göre; Afganistan Emiri ile İngiltere arasındaki politika gereği yurt dışına çıkan Afganlılara pasaport vermek ve himaye etmek vazifesi İngiltere'ye aitti. Bu nedenle Osmanlı topraklarında ikamet eden Afgan mültecileri için gerekli hallerde himaye ve korunmaları hususunda İngiliz konsoloslarına talimat verileceğini Osmanlı hükümetine bildirmişti. Ayrıca İngiltere büyükelçiliği, aslen Afganistanlı olan muhacirlerin Kraliçe'nin Hindistan tebaasından bulunanlar ile aynı haklara haiz olduklarını ileri sürerek Dâhiliye Nezareti'nin göndermiş olduğu söz konusu talimatı geri alması isteniyordu

Babıali ise, müstakil bir devletin yurt dışında bulunan vatandaşlarının himayesini bir başka devlete bırakabileceğini kabul etmekteydi. Fakat bunların hâmisi olan devletin himayesi altına altığı muhacirleri kendi vatandaşları mesabesinde değerlendiremeyeceğini ve dolayısıyla Afganlıların ne bir İngiliz'in ne de Hindlinin mevcut imtiyaz ve haklarına sahip olamayacağını düşünmekteydi. Üstelik Afgan Emiri ile İngiltere arasındaki antlaşma neşredilmediği için Afganistan dışındaki Afganlılarının ne gibi şartlara haiz olduklarının bilinmediği belirtilmekteydi. ${ }^{15}$

\footnotetext{
${ }^{12}$ Aybars Pamir, “Kapitülasyon Kavramı ve Osmanlı Devleti'ne Etkileri”, Ankara Üniversitesi Hukuk Fakültesi Dergisi, C. LI, S. 2, 2002, s. 106.

${ }^{13}$ Raporun sonunda, Afgan ahalisinden Hacı Habib'in memleketi bağımsız iken Osmanlı topraklarına göç ettiği ve kendi istediği doğrultusunda otuz seneden fazla Bağdat'ta ikamet ettiği için İngiliz himayesine geçme hakkının bulunmadığı ifade edilmiştir.; BOA., ŞD., 2505/15/7, 1 Mart 1886.

${ }^{14}$ BOA., HR.SYS., 593/4/4, 15 Haziran 1886.

${ }^{15}$ BOA., HR.SYS., 593/4/82, 26 Haziran 1890.
} 
Afgan muhacirlerin tâbiiyet ve himaye meselesine ilişkin olarak İngiliz büyükelçiliğinden Babıali'ye 12 Ağustos 1890 tarihli bir yazı daha gönderilmişti. Bu yazıda İngiltere tâbiiyetine girmedikçe Afganlıların kendi vatandaşlarına verilen imtiyazlardan yararlanmayacakları ifade edildiği gibi Hindistan ahalisinden de sayılamayacaklarının kabul edildiği belirtilmekteydi. Fakat yaklaşık bir ay sonra İngiliz büyükelçiliğinden gönderilen bir başka yazıyla Afgan muhacirleri üzerinde himaye hakkı yeniden gündeme getirilmekteydi. Bu yazıda Afganistan'ın İngiltere dışındaki devletlerle doğrudan ilişki kurmasını yasaklayan bir tebligattan söz edilmekteydi. İşte bu tebligata binaen İngiltere, Afgan muhacirler üzerinde himaye hakkı olduğunu iddia etmekteydi ${ }^{16}$

Sözü edilen tebligatın Hindistan valisi tarafindan Afgan emiri Abdurrahman Han'a gönderilen bir nota olduğu anlaşılmaktadır. İngiltere, Afganistan'a iç işlerine müdahale etmeyeceği, Kabil'de sadece bir Müslüman temsilcisinin bulunacağı ve dışarıdan bir saldırı olması durumunda derhal Afganistan'a yardımda bulunacağı garantisini vermişti. Bunlara karşılık Afgan Emirinin harici ilişkilerinde kayıtsız olarak İngiltere'nin nasihatlerine uyması şart koşulmuştu. ${ }^{17}$

Söz konusu gelişmeler üzerine bir kere daha konuyu ele alan Babıali Hukuk Müşavirliği, bu notanın Afgan muhacirler üzerinde İngiltere'ye yarı resmi himaye hakkı vermekte yeterli olup olmadığına Osmanlı hükümetinin karar vermesi gerektiğini belirtmekteydi. Eğer yeterli görülürse bir an önce vilayetlere talimat verilmesi gerektiği bildirilmekteydi. ${ }^{18}$ Konu hakkında görüş bildiren Hariciye Nezareti, İngiltere'nin talebinin yerine getirilmesi kanaatindeydi. Fakat Kâmil Paşa başkanlığında toplanan Meclis-i Vükelâ, Hariciye Nezaretiyle aynı kanaati taşımamaktaydı. Meclis-i Vükelâ'ya göre, adı geçen notadan yurt dışındaki Afganlıların İngiltere himayesi altında olduğuna dair bir mana çıkarılamazdı. Bu nedenle, Afgan muhacirlerin eskiden olduğu gibi Hilafet makamının korumasında oldukları, İngiliz büyükelçiliğine tebliğ edilmeliydi. Fakat bundan önce büyük devletlerin kendi topraklarına sığınan Afgan muhacirleri konusunda izledikleri politikanın öğrenilmesine karar verildi. Bunun için Osmanlı sefaretlerine birer yazı gönderilecek ve gelen cevaplar değerlendirildikten sonra İngiltere büyükelçiliğine uygun bir karşılık verilecekti. ${ }^{19}$

Osmanlı sefarethanelerinden gelen yazılardan Fransa, Almanya ve İtalya'nın Afgan muhacirlerin tâbiiyeti konusuyla pek ilgilenmedikleri anlaşılmaktadır. Zaten bu ülkelerde çok fazla Afgan bulunmamaktaydı. Fakat Babıali'nin arzuladığı asıl cevap St. Petersburg'dan gelecekti. Nitekim Rus hükümeti, Rusya'da bulunan Afganlıların İngiltere tarafından himaye edilmesi talebinin reddedildiğini bildirmişti. $^{20}$ Neticede, Osmanlı hükümeti de İngiltere'nin Afgan muhacirler üzerindeki himaye talebini kabul etmediğini ve eskiden olduğu gibi muhacirlerin hilafet makamının himayesinde bulunduğunu İngiliz büyükelçiliğine tebliğ etti.

\footnotetext{
16 BOA., HR.HMŞ.ISO., 195/43/19, 12 Ağustos 1890.

${ }^{17}$ Bu notanın Osmanlıcası için bakınız; BOA., HR.SYS., 593/4/81, 22 Şubat 1891.

${ }^{18}$ BOA., HR.SYS., 593/4/84, 30 Eylül 1890.

${ }^{19}$ BOA., MV., 63/64, 18 Şubat 1891.; BOA., HR.SYS., 593/4/84/2, 22 Şubat 1891.

${ }^{20}$ BOA., HR.SYS., 593/4/32, 3 Nisan 1891.
} 
Osmanlı hükümetinin Afgan muhacirler üzerinde kararlı tutumuna rağmen İngiliz konsolosların himaye iddialarını sonlandırmadıkları görülmektedir. Özellikle ümera sinıfindan Afgan muhacirleri tâbiiyet ve himayelerine almak istedikleri anlaşılmaktadır. Örneğin İngiltere'nin Bağdat konsolosu, iki Afgan emirine İngiliz himayesini kabul etmeleri halinde kendilerine aylık 10 bin kuruş ödeme yapılacağını vadetmişti. Bağdat vilayeti ise tehlikenin farkına vararak emirlerin hoş tutulması, en azından emirlere verilen 1000 kuruşluk maaşın zamanında ödenmesi suretiyle bu tür girişimlerin önünün alınabileceği konusunda merkezî hükümeti uyarmak gereğini duymuştu. ${ }^{21}$

Osmanlı Devleti'nin Afgan muhacirlere karşı izlediği tâbiiyet ve himaye politikasını etkileyen bir başka gelişmenin de 1893 yılında Afganistan ile İngiltere arasında imzalanan Durand Hattı Antlaşması olduğunu düşünmekteyiz. Bu antlaşma; Rusya'nın Hindistan'a ilerlemesine karşı önlem alma bahanesiyle İngilizlerin savaş tehdidi sonucunda imzalanmıştı. Bu antlaşma sonucunda Afgan Emiri Abdurrahman Han, ülkesinin güney topraklarını büyük oranda İngiltere'ye birakmak zorunda kalmıştı. Böylece Peşaver ve çevresi İngiliz yönetimine terk edilmişti. ${ }^{22}$

Tâbiiyet ve himaye meselesine dair Osmanlı arşiv belgelerinde Durand Hattı Antlaşması ile ilgili doğrudan bir bilgiye rastlayamadık. Ancak bu antlaşmadan sonraki yıllara ait belgelerde, daha önce Afgan muhacirler üzerinde İngilizlerin tâbiiyet ve himaye iddialarını kabul etmeyen Osmanlı Devleti'nin, Durand Hattı Antlaşması sonrasında bazı değişikliklere gittiği görülmektedir. Artık muhacirlerin Afganistan'ın hangi bölgesinden geldikleri büyük önem taşımaktadır. Doğrudan doğruya Afgan emirinin idaresinde olan yerlerden gelen Afgan muhacirleri, eskiden olduğu gibi Osmanlı Devleti'nin ve halifenin himayesindeydiler. Fakat işgal altında olan yerlerden gelenler için İngiltere'nin yarı resmi himayesi kabul edilmeye başland. ${ }^{23}$ Böylece Afgan muhacirlerin himayesi konusunda yeni bir hukuki çerçeve belirlenmiş oldu.

\section{Afgan Muhacirlerin Osmanlı Tâbiiyetine Geçişi}

Osmanlı Devleti'nin arzu eden Afgan muhacirlerinin kendi tâbiiyete geçişlerini kolaylaştırdığını hatta teşvik ettiğini söyleyebiliriz. ${ }^{24}$ Tâbiiyet işlemleri, yukarıda zikrettiğimiz kararlara uygun şekilde ve 1869 yılında çıkarılan Osmanlı Tâbiiyet Kanunu çerçevesinde yapılmaktaydı. Daha önce belirtildiği gibi Afgan muhacirler, eğer tâbiiyet müracaatında bulunmamış ise tâbiiyet kanunun dokuzuncu maddesine bağlıydılar. Bunlar ikamet ettikleri sürece Osmanlı tebaası gibi muamele görmekteydiler.

\footnotetext{
${ }^{21}$ BOA., BEO., 1153/86416/2, 20 Haziran 1314.

${ }_{22}^{2}$ Mehmet Saray, Dünden Bugüne Afganistan, Boğaziçi Yayınları, İstanbul 1981, s. 115-116.; Orhan Yazıc1, Modern Afganistan'ın Kuruluşu 1834-1922, Huzur Cilt Evi, Malatya 2011, s. 153-156.

${ }^{23}$ BOA., HR.SYS., 593/4/62, 07 Kasim 1895.

24 Basra vilayet tercümanlarından İlyas Şami birkaç yüz İranlı ve Afganlı muhacirin Osmanlı tâbiiyetine geçmesinde katkılarından dolayı dördüncü rütbeden Mecidi nişanı ve bir derece terfi ile taltif edilmişti. Bkz. BOA., DH.MKT., 803/66, 20 Aralık 1903.
} 
Tâbiiyet Kanunun üçüncü maddesine göre beş yıl boyunca Osmanlı topraklarında ikamet eden bir yabancı Osmanlı vatandaşlığına geçmek için Hâriciye Nezareti'ne müracaatta bulunabilirdi. Beş yıllık ikamet sürecini tamamlayanlardan Osmanlı tâbiiyetine geçmek isteyenlerin müracaatları uygun bulunursa, tâbî oldukları devlet konsolosluklarına tâbiiyet değiştirmelerinde bir engel bulunup bulunmadığı soruluyor ve konsolosların 15 gün içerisinde cevap vermeleri bekleniyordu. Örneğin Seyyid Ahmed isimli bir Afgan Suriye vilayetinde Osmanlı tâbiiyetine geçmek için müracaatta bulunmuştu. Fakat Seyyid Ahmed'in Avusturalya'dan aldığ 1 bir pasaportunun olduğu ortaya çıkmıştı. Osmanlı topraklarına gelişi üzerinden sadece üç yıl geçtiği gerekçesiyle müracaatı reddedilmiş ve iki yıl sonra yeniden başvurması istenmişti. $^{25}$

Osmanlı tâbiiyetine geçmek isteyen Afgan muhacirlerinin eğer İngiltere işgali altındaki bölgelerden gelmedilerse tâbiiyet müracaatlarının doğrudan kabulü usulü benimsenmişti. $\mathrm{Bu}$ anlamda Afgan muhacirleri için Tâbiiyet Kanunun dördüncü maddesinin uygulandığını ifade etmek mümkündür. Zira istisnai olarak bu madde muhacirlere beş yıllık ikamet şartı aranmaksızın vatandaşlık hakkı verilmesine izin veriyordu. ${ }^{26}$ Aslında dördüncü madde genellikle Osmanlı Devleti'ne hizmet eden veya Müslümanlığı kabul eden kişiler için uygulanmış ise de ${ }^{27}$ Osmanlı vatandaşı olmak isteyen Afgan muhacirlerinin de aynı kapsamda değerlendirildiği görülmektedir.

Tâbiiyet müracaatında bulunan Afganlıların iyi ahlaklı olması, herhangi bir suçtan mahkûmiyetinin bulunmaması ve bir daha memleketine dönmemeği taahhüt etmesi yeterliydi. Bu kişilerin Osmanlı tâbiiyetine kabulüne ilişkin düzenlenecek belgelerde ismi, şöhreti ve hangi tarihten beri Osmanlı topraklarında ikamet ettikleri belirtilmeliydi. Daha önce ifade ettiğimiz gibi bu tür müracaatlar sadece Afgan emirinin doğrudan idaresi altında olan bölgelerden göç eden muhacirler için geçerliydi. ${ }^{28}$ Ayrıca Osmanlı vatandaşlığına geçmek isteyen her muhacir gibi ${ }^{29}$ Afganlar da bir daha eski tâbiiyetlerine geçmeyeceklerine dair bir senet imzalamaları gerekmekteydi.

Görüldüğü üzere, tâbiiyete müracaat eden kişinin Afganistan'ın hangi bölgesinden geldiği ve bu bölgenin kim tarafından idare edildiği oldukça önemliydi. Doğal olarak bu durum, bazen karışıklıklara yol açabilmekteydi. Bunun önüne geçmek için Afgan Emiri ve İngiltere idaresindeki bölgeleri gösteren haritalar ile aralarında yapılmış olan antlaşmaların suretleri Londra sefaretinden talep edilmekteydi. ${ }^{30}$

${ }^{25}$ BOA., DH.I.UM.EK., 95/120, 04 Ekim 1915.

${ }^{26}$ İbrahim Serbestoğlu, "Zorunlu Bir Modernleşme Örneği Olarak Osmanlı Tâbiiyet Kanunu”, OTAM, S. 29, Bahar 2011, s. 205.

${ }^{27}$ Osmanağaoğlu, a.g.e., s. 210

${ }^{28}$ BOA., HR.SYS., 593/4/59, 23 Temmuz 1895.; BOA., HR.SYS., 593/4/58, 29 Temmuz 1895.; BOA., HR.SYS., 593/4/62, 07 Kasim 1895.; BOA., HR.SYS., 593/4/60, 05 Mart 1896.; BOA., DH.SN.THR., 47/94, 4 Ocak 1914.; BOA., DH.SN.THR., 54/45, 03 Ağustos 1914.

${ }^{29}$ Engin Kırlı, 19 ve 20. Yüzyılda Eskişehir'e Göçler, Yayınlanmamış Yüksek Lisans Tezi, Eskişehir Osmangazi Üniversitesi Sosyal Bilimler Enstitüsü, Eskişehir 2001, s. 247.

${ }^{30}$ BOA., HR.HMŞ.ișO., 195/43, 23 Ağustos 1908. 
Osmanlı topraklarında bulunan Afgan tekkelerinin muhacirler ile devlet arasında ilişkinin sağlanmasında önemli rolleri vardı. Tâbiiyet başvurusu yapan Afgan muhacirlerin durumu hakkında bilgi toplanırken de tekke şeylerine müracaat edilmekteydi. ${ }^{31}$ Ayrıca Durand Hattı Antlaşması sonrasında Osmanlı tâbiiyetine geçmek isteyenlerin Afganistan'ın hangi bölgesinden olduklarının belirlenmesi için tekke şeylerinden ilmühaber almaları gerekmekteydi. Derviş Seyyid Muhammed ve Hacı Murtaza adında iki Afganlı tâbiiyet başvurusu için hangi bölgeden göç ettiklerini gösteren ilmühaberi Üssküdar'daki Kalenderhane Şeyhinden ${ }^{32}$ almışlardı.

Kimi zaman tekkelerden alınan ilmühaberlerin sıhhati konusunda şüpheler dile getirilmekteydi. Fakat Dâhiliye Nezareti, Osmanlı tâbiiyetine geçmek isteyen Afgan muhacirlerin ilmühaberlerini, daha sıhhatli bir yol olmadığı için, mensup oldukları tekke ve zaviyelerden almalarını yeterli bulmaktayd $1 .{ }^{33}$ Afgan şeyhlerinin muhacirler üzerinde ve tâbiiyete geçişlerde yetkilendirilmesi pratik olduğu kadar II. Abdülhamid dönemine uygun bir stratejiydi. Afganistan'a nüfuz edemeyen Osmanlı Sultanı, hilafetin gücünü dergâh ve din adamları üzerinden hissettirmekteydi.

Osmanlı tâbiiyetine geçen Afganlar için askerlik meselesi de önemli bir sorundu. Nitekim 1893 yılında bir süredir Tarsus'ta yaşayan ve Osmanlı tebaasından kadınlarla evlenen 200 kadar Afganlının Osmanlı tâbiiyetine geçirilmeleri hususu Şûrâ-yı Devlet'te görüşülürken askerlik meselesi de gündeme getirildi. Osmanlı tâbiiyet geçecek olan Afgan muhacirlerin askerlik nedeniyle ceza alabilecekleri, yabancı devlet tebaası olduklarını iddia edebilecekleri ya da askerden firar edebilecekleri gibi hususlara dikkat çekilerek konunun Seraskerlik makamına sevk edilmesine karar verildi. Seraskerlik makamı ise Afganlıların askerlik hizmetinden aflarıyla yalnızca Osmanlı topraklarında doğan çocukları için askerlik mükellefiyetinin olması konusunda görüş bildirdi. ${ }^{34}$

II. Abdülhamid döneminden sonra İskân-1 Muhâcirin Nizamnamesinin yürürlüğe girmesiyle Buhara, Sudan ve Afganistan gibi yerlerden göç eden muhacirler için askerlik meselesi yeniden gündeme getirildi. Çünkü Muhacirîn Nizamnamesine göre, muhacirlere sadece altı yıllık askerlikten muafiyet hakk1 verilmekteydi. ${ }^{35}$ Ancak adı geçen ülkelerden göç edenler için Şûrâ-yı Devlet'in daha önce almış olduğu kararın devam ettiğini görmekteyiz. ${ }^{36}$

Afgan muhacirlere, her ne kadar Osmanlı tebaası gibi muamele edilmesine karar verilmiş olsa da Osmanlı tâbiiyetine geçmeden emlak edinmelerine izin verilmemekteydi. Aslında 16 Haziran 1869'da çıkarılan kanundan sonra Osmanlı topraklarında yaşayan yabancılar, mülk edinme hakkını elde etmişlerdi. Fakat

\footnotetext{
${ }^{31}$ BOA., DH.I.UM.EK., 95/120, 04 Ekim 1915.

32 Üsküdar'da bulunan ve Afganî Kalenderhanesi” olarak biline Nakşibendi tekkesi XVIII. yüzyılın sonunda Afganistan'dan gelen bekar ve seyyah dervişlerin barınmaları için kurulmuştu. Bkz. M. Baha Tanman "Afganiler Tekkesi", DİA, C.I, s. 400.

${ }^{33}$ BOA., DH.MKT., 813/32, 31 Ocak 1904.

${ }^{34}$ BOA., BEO 302/22647, 30 Eylül 1893.

${ }^{35}$ BOA., HR.HMŞ. ISSO., 206/25, 19 Nisan 1913.

${ }^{36}$ BOA., HR.HMŞ.ISSSO., 206/29, 05 Haziran 1913.; BOA., HR.HMŞ.íŞO., 207/14, 19 Kasım 1913.
} 
Mülkiyet kanununu kabul etmeyen devletlerin tebaalarına bu imkân verilmemişti. ${ }^{37}$ Dolayısıyla Afgan muhacirleri Osmanlı tâbiiyetine geçmeden mülk satın alamamaktaydılar.

Bağdat'ta gayrimenkul satın almak isteyen Afgan ve Keşmir ahalisinden olan muhacirlerin talepleri üzerine konu, görüşülmek üzere Meclis-i Vükelâ'ya havale edilmişti. Babıali Hukuk Müşavirliği, Afgan muhacirlere mülkiyet hakkı verilebilmesi için yeni bir kanun veya kararın çıkarılmasının gerekli olduğu hakkında bir rapor hazırladı. ${ }^{38}$ Fakat Meclis-i Vükelâ, bu konuda hazırlanacak kanun veya kararın siyasi sorunlara neden olabileceğini belirterek mülk edinmek isteyen muhacirler için tek yolun Osmanlı tâbiiyetine geçmek olduğu yönünde karar aldı. ${ }^{39}$

\section{Sonuç}

II. Abdülhamid döneminde Osmanlı Devleti, Afganistan'dan gelen bir göç dalgasıyla karşılaşmıştı. Osmanlı Devleti'nin Afganistan konusundaki politikasından şüphe duyan İngiltere'nin Osmanlı topraklarına sığınan Afgan muhacirlerinin kendi himaye ve tâbiiyetinde sayılması gerektiğine dair iddiaları gündeme taşıması kaçınılmaz olarak da tartışmaları beraberinde getirmişti. Başlangıçta Osmanlı hükümeti İngiltere'nin Afgan muhacirleri himaye hakkı konusundaki iddialarını kabul etmemişti. Fakat Durand Hattı Antlaşması sonrasında İngiliz işgali altındaki bölgelerden Osmanlı topraklarına göç eden Afgan muhacirler üzerinde İngiltere'nin himaye hakkı tanındı. Durand Hattı Antlaşması sonrasında bir parça taviz verilmiş olsa da genel itibariyle Afgan muhacirleri Osmanlı tebaası gibi muamele görmüş, halifenin himayesinde oldukları vurgulanmış ve Osmanlı tâbiiyetine geçmek isteyenlere gereken kolaylıklar sağlanmıştır.

\section{Kaynakça}

Arşiv Belgeleri:

Başbakanlık Osmanlı Arşivi (BOA)

Babiali Evrak Odas1 (BEO): 302/22647, 1153/86416/2.

Dahiliye Ecanib Kalemi (DH.EUM.ECB.): 9/19.

Dahiliye Mektubi Kalemi (DH.MKT.): 803/66, 813/32.

Dahiliye İdare-i Umumiye Ekleri (DH.İ.UM.EK.): 95/120.

Dahiliye Sicil-i Nüfus Tahrirat Kalemi (DH.SN.THR.): 47/94, 54/45.

Hariciye Nezareti İstişare Odası (HR.HMŞ.İŞO.): 195/43/19, 206/25, 206/29, 207/14.

Hariciye Siyasi (HR.SYS.): 593/4/4, 593/4/32, 593/4/58, 593/4/59, 593/4/60, 593/4/62, 593/4/81, 593/4/82, 593/4/84.

Hariciye Tercüme Odası (HR.TO.): 370/35.

Meclis-i Vükela Mazbataları (MV.): 17/38.

Şura-yı Devlet (ŞD): 2505/15/7.

\footnotetext{
${ }^{37}$ Nedjib H. Chiha, "Osmanlı Devletinde Gayrimenkul Mülkiyeti Bakımından Yabancıların Hukuki Durumu”, Ankara Üniversitesi Hukuk Fakültesi Dergisi, Çev. Halil Cin, C. XXIV, S. 1, s. 271-272.

${ }^{38}$ BOA., HR.TO., 370/35, 22 Eylül 1886.

${ }^{39}$ BOA., $M V .$, 17/38, 17 Mart 1887.
} 
Kitap ve Makaleler:

Buzpınar, Ş. Tufan, "Suriye'ye Yerleşen Muhacirlerin Tâbiiyeti Meselesi (1847-1900)" İslâm Araştırmaları Dergisi, S. 1, 1997, s. 91-106.

Chiha, Nedjib H., "Osmanlı Devletinde Gayrimenkul Mülkiyeti Bakımından Yabancıların Hukuki Durumu”, Ankara Üniversitesi Hukuk Fakültesi Dergisi, Çev. Halil Cin, C. XXIV, S. 1, s. 247-274.

İpek, Nedim, Rumeli'den Anadolu'ya Türk Göçleri (1877-1890), Ankara 1994.

Kırlı, Engin, 19 ve 20. Yüzyllda Eskişehir'e Göçler, Yayınlanmamış Yüksek Lisans Tezi, Eskişehir Osmangazi Üniversitesi Sosyal Bilimler Enstitüsü, Eskişehir 2001.

Osmanağaoğlu, Cihan, Tanzimat Dönemi İtibariyle Osmanlı Tâbiiyetinin (Vatandaşlı̆̆ının) Gelişimi, Legal Yayınc1lı, İstanbul 2004.

Özcan, Azmi, "II. Abdülhamid Döneminde Afganistan ile İlişkiler ve İngiltere", Afganistan Üzerine Araştırmalar, Yay. Haz. Ali Ahmetbeyoğlu, TATAV Yayınları, İstanbul 2002, s. 83-102.

Pamir, Aybars, "Kapitülasyon Kavramı ve Osmanlı Devleti’ne Etkileri”, Ankara Üniversitesi Hukuk Fakültesi Dergisi, C. LI, S. 2, 2002, ss. 79-119

Saray, Mehmet, Dünden Bugüne Afganistan, Boğaziçi Yayınları, İstanbul 1981

Serbestoğlu, İbrahim, "Zorunlu Bir Modernleşme Örneği Olarak Osmanlı Tâbiiyet Kanunu”, OTAM, S. 29, Bahar 2011, ss. 193-214.

Tanman, M. Baha, "Afganiler Tekkesi”, DIA, C.I, s. 400.

Yazıc1, Orhan, "Birinci İngiliz-Afgan Savaşı ve Sonuçları", Afganistan Üzerine Araştırmalar, Yay. Haz. Ali Ahmetbeyoğlu, TATAV Yayınları, İstanbul 2002, s. 51-82.

Yazıcı, Orhan, "Emir Abdurrahman Han'ın Afganistan'da Merkezî Otoriteyi Tesis Etme Çabaları", Orta Doğu Araşttrmaları Dergisi, C. VII, S. 1, Ocak 2009, s. 95-118.

Yazıc1, Orhan, Modern Afganistan'ın Kuruluşu 1834-1922, Huzur Cilt Evi, Malatya 2011. 